\title{
A new species of Scymnobius Casey (Coleoptera, Coccinellidae, Scymnini) from Pernambuco, Brazil
}

\author{
José Adriano Giorgi ${ }^{1} \&$ Guillermo González²
}

\author{
${ }^{1}$ Universidade Federal do Pará, Faculdade de Ciências Biológicas, Rua José Porfírio, 2515. \\ São Sebastião, 68372-040 Altamira-PA, Brazil. coccinellid@gmail.com \\ ${ }^{2}$ Nocedal 6455, La Reina, Santiago, Chile. willogonzalez@yahoo.com
}

\begin{abstract}
A new species of Scymnobius Casey (Coleoptera, Coccinellidae, Scymnini) from Pernambuco, Brazil. Scymnobius pernambucensis sp. nov. from Pernambuco, Brazil, is described and illustrated. This is the third species of this genus recorded from Brazil.

KEYWORDS. Insecta; ladybird beetle; predator; taxonomy; whitefly.
\end{abstract}

Scymnobius Casey is a poorly known Scymnus-like genus from the New World with 21 species currently described, 11 of them from South America. The North American species were revised by Gordon $(1976,1985)$ who, following previous authors, treated this taxon as a subgenus of Nephus. The generic status of Scymnobius was recognized by Gordon \& González (2002) in the revision of the South American fauna of the genus. The genus is characterized by having a 10-segmented antennae with the last four antennomeres forming a club, incomplete postcoxal line and tarsi with three tarsomeres.

The scarce information on the biology of Scymnobius is based almost exclusively on label data association. Gordon (1985) and Gordon \& González (2002) regarded the genus as a predator of mealybugs (Hemiptera, Pseudococcidae). Gordon \& González (2002) also reported whitefly association for the South American species from label data, but suspected Scymnobious is no true predator of whiteflies. Regardless of its preference of prey, there is no record of this genus ever being used for biological control purposes.

In this contribution, we describe the third species from Brazil. The specimens were collected during a coccinellid survey in the state of Pernambuco. The two other species recorded for the country are Scymnobius caliginosus Gordon and González and Scymnobius obscurus (Mulsant).

\section{MATERIAL AND METHODS}

The following acronyms are used in the text to indicate specimen depositories and institutional affiliations: USNM - United States National Entomological Collection, U.S. National Museum of Natural History, Washington, D.C., USA, and DZUP - Coleção Entomológica Pe J. S. Moure, Departamento de Zoologia, Universidade Federal do Paraná, Curitiba, PR, Brazil.
Dissections were performed with the aid of a stereomicroscope and standard dissection tools. Temporary mounts were prepared in glycerin for microscopic examination. Male and female genitalia were soaked in a $10 \%$ solution of $\mathrm{KOH}$ to dissolve excess tissue and partially clear opaque structures. After examination, the genitalia preparations were stored in glycerin in a genitalia vial pinned with the specimen. Terminology used in the description of genitalic structures follows Gordon (1985).

\section{TAXONOMY}

Scymnobius pernambucensis sp. nov.

(Figs. 1-26)

Description. Male, length 1.8-1.9 mm; body rounded, slightly elongate, widest anterior to middle elytra. Dorsal surface shiny. Color predominantly reddish brown. Elytra with dark brown basal border, somewhat triangular, not reaching humeral callus laterally, extending posteriorly along sutural margins to apex (Figs. 1-6); pronotum mostly black, except for lateral borders and a thin line along anterior border reddish brown; pro-, meso- and metasterna black; abdominal ventrites 1-4 mostly black, except by lateral borders. Head punctures coarse, sparse medially, separated by less than twice the diameter, denser near eyes, separated by one diameter or less. Pronotal punctures finer than on head, separated by twice their diameter. Elytral punctation as course as head, separated by one diameter or less. Metasternal punctures coarser than on elytron, separated by one diameter or less medially, becoming coarser and almost contiguous near lateral margin. Abdominal punctures as coarse as on elytron, separated by 1 to 2 times their diameter on ventrites $1-3$, denser on ventrites $4-6$, separated by one diameter or less. Dorsum with pubescence sparse, grayish white, slightly decumbent, individual hairs as long as scutel- 

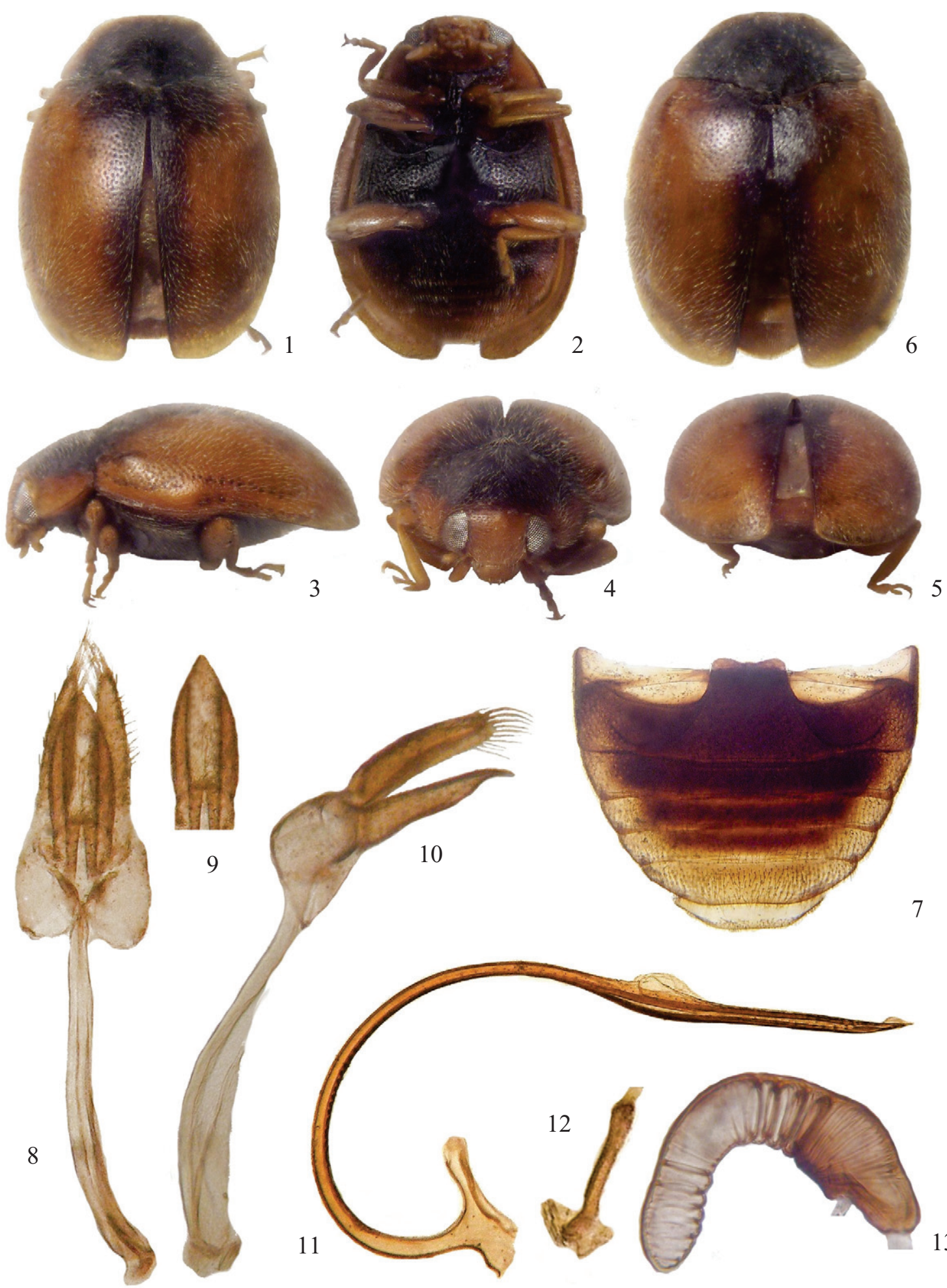

Figs. 1-13. Scymnobius pernambucensis sp. nov. 1-5, male habitus. 1, dorsal; 2, ventral; 3, lateral; 4, frontal; 5, posterior. 6, female, dorsal habitus; 7, ventral view of abdomen; 8 , ventral view of tegmen; 9 , ventral view of basal lobe in detail; 10, lateral view of tegmen; 11 , lateral view of sipho; 12 , dorsal view of infundibulum; 13, dorsal view of spermatheca.

lum. Prosternal process wide, parallel sized, with a well-marked carina, coarsely punctured, punctures contiguous. Postcoxal line on 1st abdominal sternite extended over four-fifths of the distance to posterior sternal margin, basal half gradually curved, apical half slightly recurved apically, apex separated from lateral sterna margin by one-eighth the length of ventrite 2 . Apex of 5th ventrite broadly, weakly rounded; apex of 6 th sternum wide, feeble emarginated (Fig. 7). 
Genitalia with basal lobe symmetrical, slightly shorter than paramere, in ventral view, sides straight, slightly divergent on basal one-third, ogival at apex (Figs. 8-9); in lateral view, compressed toward apex, which is bent, without basodorsal protuberance (Fig. 10); paramere long, slender, tapering on apex; sipho strongly curved on basal half, apical half straight with a membranous widened area midway on the outer side, tapering on apex; inner arm of basal capsule long, not angled posteriorly, about twice as long as the short, truncate outer arm (Fig. 11).

Female. Similar to male (Fig. 6). Apical margin of 6th ventrite rounded. Genitalia with spermathecal capsule strongly curved medially, ramus slender, long, with short basal projection, cornu unmodified, without beak. Infundibulum long, about two-fifths as long as spermatheca, tubular (Figs. 12-13).

Type Material. Holotype male, Brazil: Pernambuco, Recife, UFRPE [Universidade Federal Rural de Pernambuco], Área Experimental, em algodão, III-2011, leg. Adriano Giorgi (DZUP). Paratypes: 2 males and 2 females, same data as holotype (2 DZUP; 2 NMNH).

Etymology. The species is named for the state of Pernambuco, Brazil, where the type material was collected.

Remarks. The species is here treated under Scymnobius based on its 10-segmented antennae. The postcoxal line, however, fits the pattern described for the species of Nephus, which is also incomplete but curved throughout. All the other Scymnobius have the postcoxal line running parallel to the posterior border of the first abdominal ventrite.

Scymnobius pernambucensis also presents some unique genitalic features. The most distinctive one is observed in the sipho, which bears a well-developed outer membrane at the middle of the apical half. Even though a similar feature can be observed in other coccinellids (e.g., many species in the subgenus Scymnus (Pullus); see Gordon 1985), it does not occur in any species of Scymnobius. The infundibulum is also distinct in this species, which is the longest for the genus. Scymnobius pernambucensis does not share the genitalic features that characterize the "intrusus" group described by Gordon and González (2002), which makes it, by elimination, a member of the "flavifrons" group.

A single dark triangular maculation at the base of the elytra combined with the entirely brownish lateral margin of elytra distinguish this species from all the other congeners. A similar maculation can be observed in some color forms of Scymnobius bilucernarius and Scymnobius ecuadoricus.
Both species, however, have dark coloration somewhere along the elytral lateral borders.

The key to the South American species of Scymnobius in Gordon \& González (2002) should be modified as follows to include the new species:

1. Elytron mostly pale with dark maculation 2

- Elytron mostly dark with pale maculation or without any maculation

2. Elytron with maculation simple, lacking complex maculation ............................................................... 3

- Elytron with maculation complex, including J-shaped macula on disc anterior to apical declivity....

S. galapagoensis (Waterhouse)

3. Elytron with variable brown basal borders, with dark border extending to lateral margin, either anterior or posteriorly

- Elytron with a single, well defined triangular dark macula at the base; entirely pale on lateral margin S. pernambucensis sp. nov.

4. Elytron reddish yellow, basal and lateral margin with variable brown borders

S. ecuadoricus Gordon \& González

- Elytron with dark brown basal border and dark discal spot anterior to apical declivity S. triangularis Gordon \& González

\section{ACKNOWLEDGMENTS}

We thank the anonymous reviewers. The coccinellid survey was made possible through funds from FACEPE (APQ0538-5.01/10, granted to Jorge Braz Torres, Universidade Federal Rural de Pernambuco).

\section{REFERENCES}

Gordon, R.D. 1976. The Scymnini (Coleoptera: Coccinellidae) of the United States and Canada: Key to genera and revision of Scymnus, Nephus, and Diomus. Bulletin of the Buffalo Society of Natural Sciences 28: 1-362.

Gordon, R.D. 1985. The Coccinellidae (Coleoptera) of America north of Mexico. Journal of the New York Entomological Society 93: 1-912.

Gordon, R.D. \& González, G. 2002. South American Coccinellidae (Coleoptera). Part IX: A systematic revision of Scymnobius Casey (Scymninae: Scymnini). Frustula Entomologica 25: 57-85.

Received 7 August 2014; accepted 8 October 2014

Associate Editor: Lucia M. Almeida 